Western Washington University Western CEDAR

\title{
"You Look Like a Dude, Dude": Masculine Females Undoing Gender in the Workplace
}

Raine Dozier

Western Washington University, raine.dozier@wwu.edu

Follow this and additional works at: https://cedar.wwu.edu/woodring_dei

Part of the Education Commons

\section{Recommended Citation}

Raine Dozier (2019) "You Look Like a Dude, Dude": Masculine Females Undoing Gender in the Workplace, Journal of Homosexuality, 66:9, 1219-1237, DOI: 10.1080/00918369.2018.1500778

This Article is brought to you for free and open access by the Woodring College of Education at Western CEDAR. It has been accepted for inclusion in Woodring Scholarship on Diversity, Equity, Inclusion by an authorized administrator of Western CEDAR. For more information, please contact westerncedar@wwu.edu. 


\title{
"You Look Like a Dude, Dude": Masculine Females Undoing Gender in the Workplace
}

\author{
Raine Dozier, PhD \\ Department of Health \& Community Studies, Western Washington University, Bellingham, Washington, \\ USA
}

\begin{abstract}
Interviews with 49 masculine females from diverse identities and occupations suggest that their workplace interactions undo gender, that is, breach rather than revise gender parameters. In this study, participants reveal that, although they were acknowledged as women in the workplace, their treatment was often more similar to men. Their classification as "like men" sometimes accrued advantage such as male camaraderie, access to information and opportunities, and greater assumed competence relative to gender-conforming women. Participants' interactions with coworkers, supervisors, and customers suggest that, rather than a pariah femininity, masculine females may more accurately be described as a subordinate masculinity. Interactions that classify masculine females as predominantly masculine or "like men" denaturalize gender. By visibly countering gender's anatomical basis and the notion of coherent gendered selves, masculine females might, in one small way, undo gender.
\end{abstract}

\section{KEYWORDS}

Female masculinity; gender theory; undoing gender; sexual orientation; masculinity; workplace; lesbian

Gender is a primary organizer of social life that serves to produce and maintain inequality. In their seminal work, West and Zimmerman (1987) described "doing gender" as interaction that produces and sustains a gender hierarchy by naturalizing differences between men and women. Doing gender in interaction is not the sole producer of gender, but one of a collection of structures and practices that establish a hierarchy among men and women and legitimize their unequal status (Budgeon, 2014). The doing gender paradigm has been an important framework in furthering gender theory and has been applied to particular instances (Pyke \& Johnson, 2003; Schilt \& Westbrook, 2009), refined (Dozier, 2005), and extended to ask whether, if we do gender in interaction, we can also undo it (Connell, 2010; Deutsch, 2007; Risman, 2009). Asking whether gender can be undone in interaction may appear to be a relatively minor question since a variety of structures and practices sustain the gender order. However, exploring vulnerabilities in the margins of social systems and, in this case, the permeability of gender 
borders may reveal possibilities for change; "no political revolution is possible without a radical shift in one's notion of the possible and the real" (Butler, 1999, p. xxiii). In this article, I suggest that masculine females provide a counterfactual to the gender order, undoing gender by illuminating its social construction and denaturalizing the gender binary.

West and Zimmerman's important work defined gender as the performance one is accountable for based on sex category. As a result, gender remains inextricably linked to sex category, leaving little room for feminine men and masculine women. Gender theorists have continued to struggle with the conflation of gender and sex category, often reverting to descriptions of gender as the social interpretation of sex and using sex as an anatomical imperative, a "coat rack" on which gender is hung (Nicholson, 1994). In addition to the persistent view that gender derives from sex (category), scholarship continues to use masculinity/femininity and man/woman interchangeably, implying that men and masculinity are inextricably linked (for notable exceptions, see Devor, 1989; Halberstam, 1998). The lack of language to capture the complexity of sex and gender leaves us to draw unsatisfying and unspecific conclusions. For example, C. Connell wrote that a transwoman participant "now sees [computer] programming in her company as gendered in a way that favors masculinity (and men as workers)" (2010, p. 48). Even in this important critical analysis of gender, masculinity and being a man are conflated and viewed as garnering similar rewards in the workplace. Yet studies suggest that women who display "masculine" behavior in the workplace are not always rewarded and are sometimes even sanctioned (Eagly \& Karau, 2002; Gorman, 2005; Heilman, Wallen, Fuchs, \& Tamkins, 2004; Johnson, Murphy, Zewdie, \& Reichard, 2008).

\section{Redoing and undoing gender}

Recent work in gender theory has addressed the changing parameters of gender including the associated behavioral expectations for men and women (Brewster \& Padavic, 2000; Budgeon, 2014; Risman, 2009). Studies suggest that "new femininities" are more androgynous, incorporating aspects of both femininity and masculinity (Budgeon, 2014; Harris, 2004). The development of new femininities coincides with a significant reconfiguration of gender within institutions such as the family, education, and the labor market (Artis \& Pavalko, 2003; Bianchi, Milkie, Sayer, \& Robinson, 2000; Deutsch, 2007; Mather, 2014). Although studies have found significant shifts in the parameters of gender domains, theorists have questioned whether it has influenced the gender hierarchy. Is it possible to undo gender, or is gender simply redone-that is, reconfigured while the hierarchy remains (Connell, 2010; Deutsch, 2007; Risman, 2009). While gender expectations have changed 
significantly over time, men and women remain accountable to hegemonic notions of gender (West \& Zimmerman, 2009).

Whereas redoing gender describes shifting gender domains, undoing gender implies a breach in gender parameters. Ideally, undoing gender describes a dismantling of the gender binary rendering its categories unintelligible and challenging the "reality of gender" (Risman, 2009; West \& Zimmerman, 1987, 2009). The concept differs from redoing gender because it describes occurrences that significantly disrupt the conflation of sex category, living as a man or woman, and masculinity and femininity, potentially provoking a category crisis (Butler, 1999).

\section{Hegemonic masculinity and doing gender}

Doing gender relies on a naturalized gender binary where individuals are categorized into two legally and socially recognized identities: men and women (Budgeon, 2014). The notion of hegemonic masculinity is critical to producing and sustaining the gender binary because it describes an idealized standard of manhood, a normative benchmark to which both women and men are held accountable (Budgeon, 2014; Connell, 1987, 1995; Schippers, 2007). The hegemonic ideal is normative, meaning that no person need fully embody it for all to be held accountable to its standards of manliness and womanliness (Connell \& Messerschmidt, 2005). Hegemonic masculinity relies on a hierarchy of masculinities including subordinate masculinities-masculinities that fall short of the masculine ideal and whose sanctioning elucidates hegemonic standards (Connell, 1987, 1995).

Schippers (2007) and Budgeon (2014) theorized the role femininities play in producing hegemonic masculinity by specifying masculinity and femininity as "complementary and hierarchical" (Schippers, 2007, p. 90). Hegemonic femininity includes ideals of womanhood that are "constructed to serve hegemonic masculinity, from which it is granted legitimacy" (Pyke \& Johnson, 2003, p. 51). Within this framework, pariah femininities are social locations that do not serve hegemonic masculinity, especially those that embody aspects of hegemonic masculinity such as being sexually inaccessible to men or displaying aggression (Schippers, 2007).

Descriptions of hegemonic masculinity generally conflate sex category and gender, implying that gender outside the binary does not exist or is not relevant. For example, when women display masculine behavior, they are not perceived as masculine, but as a stigmatized and deviant femininity (Schippers, 2007; Williams, Muller, and Kiilanski, 2012). "When a woman is authoritative, she is not masculine; she is a bitch-both feminine and undesirable" (Schippers, 2007, p. 95). We are left with the conclusion that no matter what women do, they can never attain masculine status, instead being situated as defiled women. This claim, however, does not account for 
women who, rather than possessing a particular characteristic associated with masculinity, broadly display masculinity through appearance, behavior, and interactional styles. Not accounting for masculine females shores up the gender and sex binaries by asserting that masculinity is solely the domain of men.

\section{Motivation for study}

This study uses the work experiences of masculine females to examine how interaction differs in the face of significant gender nonconformity that challenges tenets of hegemonic masculinity. They are not accounted for in hegemonic masculinity that characterizes subordinate masculinities as solely the domain of men and pariah femininities as women who embody limited masculine attributes. Masculine females can both reveal and interrogate naturalized accounts of women and men that persist in theoretical discussions of gender. In this study, I seek to both add complexity to the doing gender framework using the experiences of masculine females at work and address the more recent debate about whether it is possible to undo or only redo gender (Butler, 2004; Connell, 2010; Deutsch, 2007; Risman, 2009; West \& Zimmerman, 2009).

\section{Data and method}

This study used semistructured, in-depth interviews with 49 masculine females conducted between 2009 and $2014_{-}^{1}$ to explore how masculine females negotiate the workplace. The research participants were self-identified masculine females with a variety of gender-related identities such as butch, stud, AG (aggressive), tomboy, genderqueer, queer, and masculine lesbian. Only one participant did not currently identify as lesbian or queer, instead characterizing herself as a "butch, straight girl" who had previously lived as a lesbian. Forty-six participants preferred female pronouns, two preferred male, and one preferred gender-neutral pronouns. Of the two who preferred male pronouns, one used female pronouns in the workplace and one had transitioned but spoke about his previous work experiences as a masculine female during the interview. The sample is diverse in terms of age, race and ethnicity, geographic location, educational attainment, and occupation. Participants were from all regions of the United States, with the majority residing in the western United States (67\%), and ranged in age from 18 to 58 with an average age of 36. Forty percent of participants were people of color with a variety of racial/ethnic identities including African American (11), Latina (2), Filipina (2), Middle Eastern (2), Samoan (1), Latina/Native American (1), and mixed race (1). All the participants graduated from high school or had GEDs, and $57 \%$ had a bachelor's or graduate degree. Participants held a variety of jobs including 
cook, retail sales person, carpenter, teacher, project manager, office worker, electrician, farrier, nurse practitioner, security guard, IT worker, technical writer, barber, legal adjudicator, and subway mechanic.

I used several strategies to recruit participants, including making contact through acquaintances and posting on the social networking site Facebook. In an effort to increase the diversity of the sample, I posted Craigslist personal ads in locations that had significant numbers of racial/ethnic minority residents, including Baltimore, Atlanta, Houston, San Diego, and Los Angeles. In the posting, I briefly explained the study and offered \$20 in exchange for participants' time. I also incorporated several subcultural terms for masculine females in the post, including masculine-of-center, butch, stud, aggressive, genderqueer, and trans, and I stressed that participants could have any type of job or experience. This strategy garnered a diverse sample that significantly contributed to my understanding of the experiences of masculine females in the workplace.

The interviews used a broad set of questions to facilitate conversation related to female masculinity in the workplace. During the interview, I used follow-up questions as warranted and encouraged participants to go "off script" to discuss anything they thought was interesting or important about their experiences as a masculine female, especially as it related to work. Inperson interviews primarily took place in coffee shops or other public settings and, occasionally, in a participant's home. Approximately half of the interviews were conducted by telephone. The interviews were digitally recorded and transcribed verbatim by paid transcribers or me. To ensure accuracy, I carefully read through all transcripts and, using the recordings, corrected any errors.

Data were analyzed using thematic analysis to identify patterns in the experiences of participants and to capture key insights related to the research question (Braun \& Clarke, 2006). The thematic analysis process is inductive and involved collecting data through participant-directed, semistructured interviews, reading resultant transcripts in their entirety to gain a broad sense of the experiences of participants, identifying central themes in participants' accounts, then sorting data into the identified themes (Creswell, 2013). This method is well suited for an analysis of under-researched groups because of its inductive approach. While considering each interview as a whole, I made notes regarding themes and particularly insightful comments from each interview. After developing a set of themes, text sections from each interview were sorted into them using Version 10 of NVivo software (QSR International, 2014). This process allowed me to investigate experiences and insights both within the context of an individual's account and within thematic categories.

Throughout the article, I refer to the participants as masculine females for simplicity's sake. Individuals do not typically hold the identity "masculine 
female" and often strongly identify with other masculine identities that hold great significance, serving to structure both identities and social relations. In discussing masculine females in the aggregate, I acknowledge the obfuscation of important cultural identities that express individual social locations influenced by a variety of factors including sexual orientation, race and ethnicity, social class, and gender expression.

\section{Results and discussion}

Masculine females, like all gender expressions, exist on a continuum. Some are perceived as women who prefer styles commonly associated with men, while others are primarily perceived as men regardless of style. Masculine females defy the gender binary broadly through behavior, appearance, and interactional styles and, as a result, can profoundly disrupt usual gender practices in the workplace. While some women challenge gender norms through a limited set of practices-for example, by working in a male-dominated occupationmasculine females' appearance and everyday behavior offer a more significant disruption. They illuminate naturalized assumptions regarding gender and makes unexamined gender visible. One participant explained:

Gender taps into the deepest fears inside people and they don't know how to handle it. It's like you say, "Hello" and you're calling into question their whole entire existence. That's how they act, and you're just like "What? Pass the pepper, would ya?"

In this study, masculine females in the workplace undo gender by challenging naturalized assumptions regarding sex-associated gender categories. Participants were often differentiated from women and viewed as more similar to men, yet they continued to assert their identity as women and/or females.

\section{Distinguished from women}

In discussing their work lives, participants described interactions with women at work that often differentiated them from gender-typical women. A production assistant at a television station discussed women in her workplace: "In Oklahoma, it was a lot of time spent talking about guys and shoes and clothes, a lot of time spent on hair... And I think being a more masculine individual those are things I'm not thinking about." Another participant talked about gender dynamics in the breakroom at a retail electronics store, taking care to differentiate herself from her women coworkers: "They're in there talking about Love and Hip-Hop or Basketball Wives or something crazy... They're more chatty and gossipy which I don't have time for." 
While these examples could be viewed as reifying gender by describing women in stereotypical ways, these participants also viewed themselves as women, albeit women who did not conform to gender expectations. In addition to differentiating themselves from women coworkers, some participants reported being treated differently than women coworkers, receiving relatively greater respect and privileges. A mixologist reported that she was taken more seriously at bartending-related events and competitions "because men involved in the industry might be able to recognize some sort of masculinity in me and...see some sort of credibility which I think is completely absurd." Another participant gained access to knowledge and informal training due to her masculinity:

All the auto techs back there are gentlemen... They are back there teaching me things ... telling me, "Hey, we want you to learn this the right way, so you're not messing up things that you do..." We do have another girl who's back there sometimes and she's learning the ropes... They're a lot more delicate in their approach in telling her things versus me they're more straightforward. They're more like "All right. This is what you need to know." [There's] less BS and sugarcoating.

In this case, the participant views herself as a woman as implied by her use of the phrase, "another girl," while, at the same time, she acknowledged her advantage relative to other women due to her masculinity. Whereas some participants reported that their differentiation from women on the job was affirming, others felt uneasy when coworkers tried to deny that they were women. One participant discussed negotiating her status as a mother with her male coworkers in the military:

That's a peer group where you're seen as almost a guy... Most of them have kids and when I talk about [my son], they'll always go, "Oh, [her wife] must have felt that way." And I'm like, "No, no, I'm still a woman. I didn't give birth to him, but..." And so they'll push it to her because she's more feminine, so we get to play that game.

The participant wanted to be acknowledged as a woman and, especially, as a mother. However, coworkers insisted on sorting her family into a heteronormative structure that includes a mother and father, each of whom assumes a different social role. As the masculine partner, she was categorized as the "father," even in the face of her objections.

\section{One of the guys}

Approximately half of participants worked in male-dominated occupations or settings. While coworkers acknowledged the participants as women, interactions suggested that they often viewed them similarly to men. One participant said, "It has become more evident over the past, I'd say, four 
months that I am more like a bro... I am the only female in my department." This perception was not due solely to being the only woman; participants reported that when typically gendered women joined the work group, they did not receive the same treatment as masculine females. One participant whose job as an engineer-related project manager required especially masculine behavior discussed experiences working in all-male groups over long stretches of time while negotiating the development of new projects:

One day somebody from the city brought a woman who is in the planning department to one of the meetings. And one of the guys in the room, in the middle of the meeting, he swore... He looks at this woman and said "Really, I apologize. We're not used to having a woman in the room." And I'm standing in front of the room with the marker and I look at him and I say, "Excuse me?"

Other participants reported relationships with colleagues that, while not explicitly acknowledged, appeared to gender them more similarly to men. A technical writer described her relationship with two of her male colleagues, which included considerable physical horseplay including simulated ninja fights: "He's always going 'Wah. Wah. Wah.' with his hands and then I'll go 'Pshhhh! I got you with a star...' Then my coworker Dave ... we'll pretend choke each other, something to make each other laugh." Although the setting was predominantly male, there were a few women in the work environment. When asked if horseplay at work was gendered, the participant reflected, "I don't think Raj would do that with Victoria, who is the really femmy build engineer."

In another example of how masculine females can be categorized as more similar to men than women, an electrician described being sent out on a job to protect a woman from sexual harassment:

The other woman.... feminine heterosexual...was getting sexually harassed by her boss... He would wrap his arms around her and hold onto the drill with his hands over her hand and be like, "Here, let me show you how to drill this hole." Nobody has ever done that to me... They'll get angry with me and they'll shove me and stuff, but I don't get groped.

While the participant was acknowledged to be a woman and was referred to as "she" on the job, she described difficulties such as workplace violence that are commonplace among men with contested masculinities who work in male-dominated environments. At the same time, she described women's difficulties in the workplace (e.g., sexual harassment) as common, but separate from her experience.

Being treated as one of the guys often offered advantages, especially in male-dominated settings. Participants reported they were sometimes viewed as more competent than typically gendered women. One participant believed this was due to her different work habits, which she viewed as gender-related: "The gals that we do have in this line of work, they tend 
not to want to get their hands dirty...so people usually give me automatic respect." Other times, the association with masculinity signaled competence and strength to employers: "Getting a job painting cars-even though it was from the Christians that wanted to save me-I think they felt I was more capable of doing the work, which was physical work." A young artist who worked in craft woodworking found that as her gender expression became more masculine, she was viewed as more competent: "It's definitely helped me career-wise. So, they can take me seriously. They give me more experience and they give me more responsibility because they are comfortable with me." The participant implies that masculine females gain material advantages such as access to experience and training and, also, encounter less gendered, more comfortable interactions with male coworkers.

In addition to assumed competence, one participant suggested that female masculinity was also associated with authority. She owns a small physical therapy business with her partner, whom she described as more femme than her:

I get much more respect from my employees than she does... We've had past employees where she will ask them to do something and they don't do it. And I ask them to do something and they do it. I don't have to worry that they will...think that they don't have to.

Some participants believed they received more opportunities or other aspects of male privilege, implying that masculine females are categorized differently than gender-normative women: "I think you get a little bit of the bleed over effects of some male associations with power...when someone is in between." One participant noticed her different treatment relative to other women at work, pointing to both the commonalities she had with male coworkers and the rewards to her masculinity on the job:

It's a double edged sword but it does feel good to be one of the guys... I can make a mistake and it not be the end of the world... and when I give my...opinion on things, it's a lot more valid... You know, my coworkers, obviously they know I'm a female... and I still get treated as a bro from them.... You like women like they like women... You got a lot in common with them. You can talk sports, you can do the kind of guy-ish things, then their comfort level turns up.

The participant highlights a number of aspects of the advantage masculine females can experience in male-dominated settings. They are viewed as more competent and face less scrutiny than gender-typical women. The participant believes this is built on masculine camaraderie, which "turns on a different switch," switching off gendered interaction and potentially making way for advantage in the workplace.

Being treated as "one of the guys" did not always confer advantage and was not always welcomed by participants. One participant who worked in a 
big-box hardware store explained that she had lupus and struggled to keep her job because, as a masculine person, she was expected to do more physical work:

There is a huge assumption made when you are a butch woman that you can just be a man work-wise and that's just not true... When they call for loading assistance, they don't call my 110 pound former cashier, Tina. They're either calling for me or they're calling for one of the guys. So I kind of get grouped in, with the physical labor, with the men.

Other participants would prefer not to be exposed to the sexism they encounter when treated as "one of the guys" as also documented among transmen (Dozier, 2005; Schilt, 2006). However, unlike transmen, participants who described being exposed to unwanted sexist views and behavior were perceived as women, rather than men, in the workplace. Their accounts imply coworkers classified masculine females as a type of masculinity, regardless of perceived sex. One participant talked at length about exposure to sexism in the military:

There's a huge harassment issue in the military...so then you're in this position where you're trusted to hear the locker room chat, but you're a woman... I do my best to confront and say, "Not cool." But then it's like being a kid in middle school where you don't want to be that person and then you're eating lunch by yourself. (laughing)

Being treated as one of the guys often conferred advantages to masculine females. In addition to greater comfort, participants reported masculine advantage in the work setting, including less scrutiny, assumptions of competence, and offers of additional training and knowledge. Participants' accounts suggest that although they are recognized as women, their treatment is often more similar to men. Their interactions suggest an instance of undoing gender, as they both disrupt and make visible the intractable association of gender expression and gender.

\section{Categorized as a man}

Some participants were not only treated as "one of the guys" but were perceived as men regardless of information to the contrary. A few participants had clearly female names, but in the face of their embodied masculinity, customers and clients categorized them as men. One participant reported clients and coworkers often switched her name to a genderneutral name: "I think it just works better with their idea of my gender." Clients would "decide that I said my name was Christian or that my name was Christina and I was still a man ... Most people would be pretty hell-bent on thinking that I was a man and then blocking out the name."

Another especially masculine participant lightheartedly reported numerous incidents of gender misattribution on the job. Customers, coworkers, and prospective employers assumed she was a man, even with a typically 
gendered name. In one account, she discussed her time in the military where even a written record including her name and demographic information did not deter coworkers from categorizing her as a man:

Then they're assigning me to a living space and they're just looking at my name, they're looking at me, and then they just assume and take me to a male berthing. So I would just be like, "Hey man, I'm supposed to be in the female berthing." And he's like, "Oh man, see I knew it. I mean, your first name is Bethany, I should've guessed. But you look like a dude, dude." (laughing)

Another participant discussed an awkward situation in a yoga certification program where one of the teachers could not stop calling her "he" despite numerous conversations and e-mail exchanges: "I told her, 'Listen, I know I'm really masculine... [but] I didn't have a sex change...I'm just like a dyke...' She's actually this really amazing yoga teacher. I think she was responding to my energy and she just couldn't call me 'she."'

In these incidents, coworkers and clients had difficulty accurately categorizing the participants' sex and gender even in the face of signals such as a gender-specific name or an explicit claim to a gender by the participant, revealing the intransigent relationship between masculinity/femininity and being a man/woman in conceptions of gender. Within the "two and only two" gender system, individuals classified participants as men because their masculinity was too discordant with notions of womanhood. When masculine females actively contest gender misattribution and assert their identities as women, they reveal naturalized assumptions regarding gender and make unexamined gender visible. In these interactions, gender parameters may weaken as they become less meaningful in classifying individuals.

\section{No clear gender}

A few participants "refused gender" at work either because they did not strongly identify as a man or a woman or did not want to engage in discussions of their gender in the workplace. One participant said, "I don't rule a lot of things out. Like I don't say, 'Please don't call me he or she."' An elementary school art teacher described frequent questions from students about her gender, recalling an incident with a particularly relentless student: "It must have been the same [question] of if you're a boy or a girl, and I said, 'Well, don't you think you can be both at the same time?' [laughs]." The interaction resulted in sanction by administration because parents perceived her as muddying notions of gender for their child. Because gender orders interaction, participants were not able to escape gender attribution, even in the briefest workplace interactions. The few participants who were uncomfortable with gender attribution were not grappling with a transgender 
identity but, instead, found the language and binary construction of gender inadequate to express their personal and social identity.

Participants who were especially masculine found that coworkers often had difficulty clearly placing them into one gender. A few participants believed this was an advantage-the inability to locate them as women meant that they experienced sexism differently or not at all. One participant who worked in the computer technology field believed that coworkers' difficulty in gendering her was especially advantageous, helping her secure a highly paid, professional job without a college degree. In addition, she avoided the sexism she observed when another woman joined their male-dominated team:

My gender expression...puts me in no man's land...because they don't know what category to put me in... Like they have to make up a category, and then it's less about "I'm going to treat her like a guy" or "I'm going to treat her like a woman..." My experience is that I get special consideration because people are forced to make special considerations for me.

Another participant discussed what I interpreted to be ongoing harassmentcoworkers referred to her as "it." She insisted that teasing about the inability to categorize her gender was good-natured and acknowledged her unusual social position: "At work, they don't call me a him/her, they say it's like an 'it,' unidentified. (laughing.) It's a joke. They would say, 'I am not sure is it a him? Are you a her or is it an it?"' She described a positive work environment in an office of mostly young Asian and Latino immigrants who she characterized as more open-minded than older Asians and Latinos. When I asked her to explain how this was a positive environment, she said: "My boss...he doesn't even care that my gender is unidentifiable. He calls me his son. (laughing) Whenever they tease me about this 'it' thing... he will tell my coworkers, 'Hey, leave my son alone."'

Participants' accounts suggest that their interactions might undo gender in two ways. When they are differentiated from women or treated similarly to men, it denaturalizes the relationship between sex and gender and breaches gender parameters. When masculine females refuse gender-that is, categorization within the gender binary-they contest the utility of a gender classification system at all.

\section{Sexuality}

Participants reported that in addition to having interests and behaviors in common with male coworkers, the lack of heterosexual tension fostered a different type of relationship with men. Relationships between men and women, even at work, are built on a foundation of heterosexuality (Schippers, 2007; Welsh, 1999). Female masculinity signals a non-heterosexual identity that can disrupt the heterosexual dynamic, taking sexuality off the table and removing masculine 
females from gendered relations. Without the foundation of heterosexuality to establish difference (Budgeon, 2014), masculine females report different interactions with male coworkers: "I guess in some ways it frees up people [men] who are in charge of me... and they can just figure out the work I need to be doing."

I feel like there's this barrier between heterosexual women and heterosexual men where they can't seem to get past this initial sexual thing...so they're going to initially perceive a feminine woman as a sex object and then if they can get past that... With someone who is masculine, that might not even cross their mind. So they can see other things first.

Participants' perceived sexual orientation also influenced their interactions with heterosexual women. Sexual orientation is typically defined by the genders of the participants involved in sexual and romantic interactions. Typically, heterosexual women engage in romantic and sexual relationships with men. In this study, some participants reported sexual or flirtatious relationships with heterosexual women coworkers or customers, implying that masculine females may be viewed as similar to men in some sexualized interactions. Three participants reported relationships or sexual encounters with heterosexual women at work; more often, participants reported flirting or other sexualizing behaviors. One African American participant, in her position as a hotel clerk, described challenges with women customers that required her to gracefully navigate uncomfortable situations without offending the customer:

A lot of times I feel like straight women come on before they know it, so I've learned to kind of just navigate that, downplay certain things... I had a lady call down to the front desk and ask me, "Can you send me some towels?" And I said, "Sure. Absolutely. Is there anything else I can do for you?" And she says, "What exactly are you offering?" Right? And then she starts laughing... You have to be careful because if you reject people sometimes they become bitter and they do malicious things.

Other participants report more generalized flirting behavior from heterosexual women, a complex occurrence because while it can validate masculinity, if not handled carefully, it can also jeopardize employment. Although the sample is too small to make a definitive assertion, it appeared that racial/ ethnic minority participants were more likely to be sexualized and had a greater need to develop strategies to address it. A Samoan participant worried that sexualized interactions could threaten her job:

They're always flirting with me! ... In the beginning, I would just laugh and ignore and try to change the subject, but now I usually have someone there with me, like another guy. And I just push them on to the other guy. I'm like, "Yeah, he knows more about that. You should probably talk to him about it." 
Working-class masculinities of color, especially Black masculinities, are often sexualized and associated with aggressive sexual behavior, so it is not surprising that participants of color described sexualized interactions at work as more threatening to their employment (Hill Collins, 2005). Participants' accounts of their sexualization by heterosexual women coworkers and customers suggest that, in some cases, they may more accurately be located as a subordinate masculinity rather than a pariah femininity.

\section{Masculine females as a subordinate masculinity}

In conceptualizing hegemonic masculinity, Connell $(1987,1995)$ described a set of subordinate masculinities that are in tension with hegemonic masculinity, serving to sustain it and preserve patriarchal advantage. The workplace experiences of participants closely resembled experiences of other subordinate masculinities-they significantly participate in masculinity, yet do not meet its normative benchmark. In addition, participants reported that their interactions with other subordinate masculinities were sometimes fraught, implying a struggle between similarly situated groups. For other subordinate masculinities, female masculinity could be interpreted as an additional challenge to their already-contested masculinity. For example, one participant described having little difficulty negotiating her relationships with "corporate guy boss," a description of someone who more closely aligns to the ideal of hegemonic masculinity, yet reported significant conflict with "bro guy bosses" who she viewed as similarly redefining or deconstructing masculinity.

Two participants described conflict in blue-collar positions-men in these positions may be threatened by having women on the job and view them as competition for a limited number of jobs (Latour, 2009). Yet the participants described challenges that differed from experiences reported by other women in blue-collar settings (Denissen, 2010; Moccio, 2009) and more similar to conflicts between men who inhabit subordinate masculinities. One participant reported several negative experiences that were clearly a bid for dominance while working in an equipment and tool rental shop: "I was servicing a floor sander... I was crouched down and...the parts guy came over... and farted on my head... Well obviously I was at the bottom of the pecking order, so he thought he could do that."

An electrician drew connections between her position as a masculine female and other subordinate masculinities who faced hostility when trying to gain access to highly prized union jobs: "They did the same thing to the Black men... If they don't care about you, they just use you up... So in order to keep a job, I had to work harder, so it tore my body up quicker." Workingclass masculinities are contested within the context of hegemonic masculinity and often rely on physical strength to achieve masculinity (Connell, 1995). 
The participant went on to describe her relationship with other electricians within this context:

Men are supposed to be stronger and better at being an electrician... and I'm stronger than most of the men that I've worked with. I'm ... naturally a good mechanic. So what has happened for me...is that the men that I've worked with spend a lot of time trying to one up me.

Two Black participants, one a high school teacher and the other a security guard, reported expectations of their behavior based on negative stereotypes of Black masculinity. The "stud" is a broadly understood identity in U.S. Black cultures, particularly in poor and working-class communities. The high school teacher felt scrutinized by coworkers who were waiting "for me to live up to certain stereotypes." The security guard reported that, as a stud, she was often stereotyped as aggressive and violent regardless of her behavior: "My presence alone is intimidating to some people. I don't even have to open my mouth... I'm not mad dogging you. It's nothing like that." These assumptions can have material effects - the security guard was assigned to a dangerous work setting and prevented from moving to a more desirable position: "Just the fact that I look, you know, with the short, faded haircut, I have the tattoos and everything. So, I think that's why my employer keeps me in certain areas, my look."

The difficult relationships between masculine females and other subordinate masculinities reported by participants imply that, in interaction, masculine females might be best characterized as a subordinate masculinity. If they were a pariah femininity, their treatment would be as deviant women and their sanction would address their failure at hegemonic femininity, similar to women in the trades who report incidents of sexual harassment and lack of access to knowledge and mentoring (Latour, 2009; Moccio, 2009). Instead, participants' negative experiences can be characterized as distinctly masculine including competition and physical threats and harassment, treatment similar to other subordinate masculinities in the work setting. If masculine females are located as a subordinate masculinity, then they undo gender, locating some women as fundamentally masculine and denaturalizing the relationship between sex, gender, and gender expression.

\section{Conclusion and implications}

In this study, interactions in the workplace suggest that masculine females are often differentiated from gender-typical women at work and viewed as more similar to men, by both themselves and others. While male coworkers' attitudes toward masculine females differed from attitudes toward other women, participants were still acknowledged as women and referred to as 
"she" in the workplace. Participants were treated more similarly to men, but not exactly like men.

This study adds complexity to notions of hegemonic masculinity and gender accountability and potentially offers an account of undoing gender. Conceptions of hegemonic masculinity often unintentionally conflate masculinity and being a man (Connell \& Messerschmidt, 2005; Deutsch, 2007; Martin, 2004). Hegemonic masculinity relies on the differentiation of men and women, and behavior "must become something completely different when enacted by women for the characteristics to maintain their place squarely in masculinity and their only legitimate enactment solely in the hands of men" (Schippers, 2007, p. 96). In this study though, masculine behavior does not describe limited characteristics enacted by women, but a distinct social location-a masculinity_inhabited by some women. Uncoupling masculinity from being a man is vital to theorizing gender, and incorporating female masculinity as a subordinate masculinity could help achieve this goal. While classifying masculine females as a subordinate masculinity risks further reifying gender, it might also destabilize the hegemony by distancing gender from anatomy and allowing for the possibility of women as essentially masculine.

Like hegemonic masculinity, the notion of accountability to gender is also contested by the experiences of masculine females (West \& Zimmerman, 1987, 2009). Recent reconfigurations of gender domains suggest that women can exhibit some stereotypically masculine characteristics without being classified as masculine. West and Zimmerman (2009) claimed that while gender domains have changed, accountability to gender remains. This study suggests there may be greater complexity in how men and women are held accountable to gender than previously theorized, and that accountability may differ under various conditions. Martin wrote, "Women who fail to practice femininity according to femininity stereotypes that define women as subordinate lose approval and end up with even lower status than they would otherwise" (Martin, 2003, p. 360). Yet while some masculine females may face sanctions in the workplace due to their failure to perform femininity, this study suggests others gain benefits from their association with masculinity without experiencing sanctions due to their status as women.

Gender relies on the construction of coherence between categories of "true sex, discrete gender, and specific sexuality" (Butler, 1999, p. 163), and masculine females denaturalize these assumptions. As a result, they have the potential to weaken gender differentiation in the workplace (Deutsch, 2007; West \& Zimmerman, 1987). By visibly countering gender's anatomical basis and the notion of coherent gendered selves, masculine females might, in one small way, weaken the utility of gender as a meaningful method of categorization (West \& Zimmerman, 2009). 
Even while accommodating the special case of masculine females, male coworkers continued to stereotype women, and, in some cases, gendertypical women had fewer opportunities relative to men or masculine females. Thus while the experiences of masculine females suggest that gender can be undone in workplace interactions, this undoing is unlikely to fundamentally reorganize the gender hierarchy. However, the presence of masculine females in the workplace can help reveal naturalized assumptions about gender and call into question parameters that restrict all genders. "When such categories come into question, the reality of gender is also put into crisis: it becomes unclear how to distinguish the real from the unreal. And this is the occasion in which we come to understand that what we take to be "real," what we invoke as the naturalized knowledge of gender is, in fact, a changeable and revisable reality" (Butler, 1999, p. xxiii).

\section{Note}

1. Approximately 90\% of the interviews were conducted between 2012 and 2014 .

\section{References}

Artis, J. E., \& Pavalko, E. K. (2003). Explaining the decline in women's household labor: Individual change and cohort differences. Journal of Marriage and Family, 65, 746-761. doi:10.1111/j.1741-3737.2003.00746.x

Bianchi, S. M., Milkie, M. A., Sayer, L. C., \& Robinson, J. P. (2000). Is anyone doing the housework? Trends in the gender division of household labor. Social Forces, 79, 191-228. doi: $10.2307 / 2675569$

Braun, V., \& Clarke, V. (2006). Using thematic analysis in psychology. Qualitative Research in Psychology, 3, 77-101. doi:10.1191/1478088706qp063oa

Brewster, K. L., \& Padavic, I. (2000). Change in gender-ideology, 1977-1996: The contributions of intracohort change and population turnover. Journal of Marriage and the Family, 62, 477-487. doi:10.1111/j.1741-3737.2000.00477.x

Budgeon, S. (2014). The dynamics of gender hegemony: Femininities, masculinities and social change. Sociology, 48, 317-334. doi:10.1177/0038038513490358

Butler, J. (1999). Gender trouble: Feminism and the subversion of identity. New York, NY: Routledge.

Butler, J. (2004). Undoing gender. New York, NY: Routledge.

Connell, C. (2010). Doing, undoing, or redoing gender? Learning from the workplace experiences of transpeople. Gender \& Society, 24, 31-55. doi:10.1177/0891243209356429

Connell, R. W. (1987). Gender and power. Sydney, Australia: Allen and Unwin.

Connell, R. W. (1995). Masculinities. Cambridge, UK: Polity Press.

Connell, R. W., \& Messerschmidt, J. W. (2005). Hegemonic masculinity: Rethinking the concept. Gender \& Society, 19, 829-859. doi:10.1177/0891243205278639 
Creswell, J. W. (2013). Qualitative inquiry \& research design: Choosing among five approaches. Thousand Oaks, CA: Sage Publications, Inc.

Denissen, A. M. (2010). The right tools for the job: Constructing gender meanings and identities in the male-dominated building trades. Human Relations, 63, 1051-1069. doi: $10.1177 / 0018726709349922$

Deutsch, F. (2007). Undoing gender. Gender \& Society, 21, 106-127. doi:10.1177/ 0891243206293577

Devor, A. H. (1989). Gender blending: Confronting the limits of duality. Bloomington, IN: Indiana University Press.

Dozier, R. (2005). Beards, breasts, and bodies: Doing sex in a gendered world. Gender \& Society, 19, 297-316. doi:10.1177/0891243204272153

Eagly, A. H., \& Karau, S. J. (2002). Role congruity theory of prejudice toward female leaders. Psychological Review, 109, 573-598. doi:10.1037//0033-295X.109.3.573

Gorman, E. (2005). Gender stereotypes, same-gender preference, and organizational variation in the hiring of women: Evidence from law firms. American Sociological Review, 70, 702-728. doi:10.1177/000312240507000408

Halberstam, J. (1998). Female masculinity. Durham, NC: Duke University Press.

Harris, A. (2004). Future girl: Young women in the twenty-first century. New York, NY: Routledge.

Heilman, M. E., Wallen, A. S., Fuchs, D., \& Tamkins, M. M. (2004). Penalties for success: Reactions to women who succeed at male gender-typed tasks. Journal of Applied Psychology, 89, 416-427. doi:10.1037/0021-9010.89.3.416

Hill Collins, P. (2005). Black sexual politics: African Americans, gender, and the new racism. New York, NY: Routledge.

Johnson, S. K., Murphy, S. E., Zewdie, S., \& Reichard, R. J. (2008). The strong, sensitive type: Effects of gender stereotypes and leadership prototypes on the evaluation of male and female leaders. Organizational Behavior and Human Decision Processes, 106, 39-60. doi:10.1016/j.obhdp.2007.12.002

Latour, J. (2009). Sisters in the brotherhoods: Working women organizing for equality in New York. New York, NY: Palgrave Macmillan.

Martin, P. Y. (2003). "Said and done" versus "saying and doing": Gendering practices, practicing gender at work. Gender \& Society, 17, 342-366. doi:10.1177/0891243203017003002

Martin, P. Y. (2004). Gender as a social institution. Social Forces, 82, 1249-1273. doi:10.1353/ sof.2004.0081

Mather, M. (2014). World population datasheet 2014: The decline in U.S. fertility. Population Reference Bureau. Retrieved March 19, 2015, from http://www.prb.org/Publications/ Datasheets/2014/2014-world-population-data-sheet/us-fertility-decline-factsheet.aspx

Moccio, F. (2009). Live wire: Women and brotherhood in the electrical industry. Philadelphia, PA: Temple University Press.

Nicholson, L. (1994). Interpreting gender. Signs: Journal of Women in Culture and Society, 20, 79-105. doi:10.1086/494955

NVivo [Computer software]. (2014). Burlington, MA: QSR International Pty Ltd.

Pyke, K. D., \& Johnson, D. L. (2003). Asian American women and racialized femininities: 'Doing' gender across cultural worlds. Gender \& Society, 17, 33-53. doi:10.1177/ 0891243202238977

Risman, B. (2009). From doing to undoing: Gender as we know it. Gender \& Society, 23, 81-84. doi:10.1177/0891243208326874

Schilt, K. (2006). Just one of the guys: How transmen make gender visible at work. Gender \& Society, 20, 465-490. doi:10.1177/0891243206288077 
Schilt, K., \& Westbrook, L. (2009). Doing gender, doing heteronormativity: "Gender normals," transgender people, and the social maintenance of heterosexuality. Gender \& Society, 23, 440-464. doi:10.1177/0891243209340034

Schippers, M. (2007). Recovering the feminine other: Masculinity, femininity, and gender hegemony. Theory and Society, 36, 85-102. doi:10.1007/s11186-007-9022-4

Welsh, S. (1999). Gender and sexual harassment. Annual Review of Sociology, 25, 169-190. doi:10.1146/annurev.soc.25.1.169

West, C., \& Zimmerman, D. H. (1987). Doing gender. Gender \& Society, 1, 125-151. doi:10.1177/0891243287001002002

West, C., \& Zimmerman, D. H. (2009). Accounting for doing gender. Gender \& Society, 23, 112-122. doi:10.1177/0891243208326529

Williams, C, Muller, C, \& Kilanski, K. (2012). Gendered organizations in the new economy. Gender \& Society, 26, 549-573. doi: 10.1177/0891243212445466 